\title{
PENJABARAN PANCASILA DALAM PASAL-PASAL NRI 1945
}

\author{
Nama Mahasiswa : Willy Dechapry Tasirileleu \\ Email: willydechaprytasirileleuwilly@gmail.com \\ No BP: 20220091 \\ Perguruan Tinggi AKBP'KBP' Padang
}

\section{A. Pendahuluan}

Pancasila adalah nilai-nila kehidupan Indonesia sejak zaman nenek moyang sampai saat ini. Berdasarkan hal tersebut terdapatlah perbedaan antara masyarakat Indonesia dengan masyarakat lain. Nilai-nilai kehidupan tersebut mewujudkan amal perbuatan dan pembawaan serta watak orang Indonesia. Dengan kata lain masyarakat Indonesia mempunyai ciri sendiri, yang merupakan kepribadianya. Dengan nilai-nilai tersebut rakyat Indonesia melihat dan memecahkan masalah kehidupan ini untuk mengarahkan dan mempedomi dalam kegiatan kehidupanya bermasyarakat. Demikianlah mereka melaksanakan kehidupan yang diyakini kebenaranya. Itulah pandangan hidupnya, karena keyakinan yang telah mendarah daging itulah maka pancasila dijadikan dasar negara serta ideologi negara. Itulah kebulatan tekad rakyat Indonesia yang ditetapkan pada tanggal 18 Agustus 1945 melalui panitia persiapan kemerdekaan Indonesia.

Bangsa Indonesia wajib bersyukur kepada Tuha Yang Maha Esa karena sampai sekarang ini tetap dapat menjaga keutuhan wiayah Negara Kesatuan Republik Indonesia (NKRI) yang ber-bhinneka Tunggal Ika Berdasarkan Pancasila. Hal ini patut diungkapkan karena Uni Soviet sebagai salah satu negara adi kuasa di sampin Amerika serikat telah menglami kehancuran.

\section{Rumusan masalah}

1. Apakah Fungsi Dari Pancasila Sebagai Dasar Negara ?

2. Bagaimana hubungan pancasila dalam UUD 1945 ?

\section{Tujuan}

1. Mengetahui Fungsi Dari Pancasila Sebagai Dasar Negara

2. Mengetahui hubungan pancasila dalam UUD 1945 


\section{B. PEMBAHASAN}

Nilai-nilai yang terdapat dalam pandangan hidup masyarakat, pandangan hidup bangsa dan pandangan hidup negara yang disebut dengan pancasila tidak bersifat statis. Artinya dalam kehidupan bermasyrakat, berbangsa, dan bernegara, ketiga bentuk pandangan hidup itu terus-menerus berinteraksi secara timbal-balik. Selalu ada benang merah yang tidak boleh putus atau diputuskan diantara ketiganya. Rangkaian proyeksi dari padangan hidup masyarakat ke pandangan hidup bangsa, lalu kepandangan hidup negara itu, terutama dibangun melalui jalur sistem hukum.

Berdasarkan latar belakang pemikiran itulah, "hukum" adalah satu kata kunci yang sangat penting untuk menjawab pertanyaan tentang dasar dan rambu-rambu pembangunan masyarakat Indonesia baru dalam era globalisasi. Namun norma hukum tentu saja bukan satu-satunya norma yang dijadikan acuan.

Ajaran filsafat bernegara bangsa indonesia yang dibingkai dalam sebuah ideologi negara yang disebut pancasila merupakan landasan utama semua sistem penyelenggaraan negara indonesia. Hukum sebagai produk negara tidak dapat dilepaskan dari falsafah negaranya. Dalam pandangan seperti ini, maka filsafat hukum pun tidak dapat dilepaskan dari pemikiran filsafati dari negaranya.

Terkait dengan hal itu, menurut Moh. Mahfud MD (Konggres Pancasila I, 2009) dalam pembentukan negara hukum, maka pancasila haus melahirkan kaidahkaidah penuntun dalam pembuatan politik hukum atau kebijakan negara lainya yaitu: (1) kebijakan umum dan politik hukum harus tetap menjaga intergrasi atau keutuhan bangsa baik secara ideologi maupun secara teriotoris, (2) kebijakan umum dan politik hukum haruslah didasarkan pada upaya membangun demokrasi (kedaulatan rakyat) dan demokrasi (kedaulatan rakyat) dan nomokrasi (negara hukum) sekaligus, (3) kebijaka umum dan politik hukum haruslah didasarkan pada upaya membagun keadilan sosial bagi seluruh rakyat indonesia, (4) kebijakan umum dan politik hukum haruslah didasarkan pada prinsip toleransi beragama yang berkeadaban.

Konsekwensinya nilai-nilai Pancasila, secara yuridis harus dideriasikan kedalam UUD Negara Indonesia dan selanjutnya pada seluruh peraturan perundangan-undangan lainnya. Dalam kedudukan seperti ini pancasila telah memiliki legitimasi filosofis, yuridis dan politis. Dalam kapasitas ini pancasila telah diderivasikan dalam suatu norma-norma dalam kehidupan kenegaraan dan bebangsa. 
Berdasarkan norma-norma peratuan perundangan-undangan tersebut dapat dapat diemplementasikan realisasi kehidupan kenegaraan yang berifat praksis. Oleh karena itu tidak mungkin implementasi dilakukan secara langsung dari pancasila kemudian direalisasikan kedalam berbagai konteks kehidupan, karena harus melalui penjabaran dalam suatu norma yang jelas. Banyak kalangan memandang hal tersebut rancu seakan-akan memandang pancasila itu secara langsung bersifat operasional dan praksis dalam berbagai konteks kehidupan bermasyarakat, kenegaraan dan kebangsaan. Sebenarnya secara eksplisit UU No. 12 Tahun 2011 tentang Pembentukan Peraturan Perundang-Undangan Pasal 2 menyatakan:"Pancasila merupakan sumber dari segala sumber hukum negara". Namun tidak dipungkiran banyak perundangan-undangan yang tidak bersumber dengan nilai-nilai luhur pacasila, yang tentunya hal ini sangat memprihatinkan dan harus segera diakhiri.

Dalam sistem tertib hukum indonesia, penjelasan UUD 1945 menyatkan bahwa pokok pikiran itu meliputi suasana kebatinan dari undang-undang dasar negara indonesia serta mewujudkan cita-cita hukum, yang menguasai hukum dasar tertulis (UUD) dan hukum dasar tidak tertulis (konfrensi), selanjutnya pokok pikiran itu dijelmakan dalam pasal-pasal UUD 1945. Maka dapatlah di simpulkan bahwa suasana kebathinan undang-undang dasar 1945, tidak lain di jiwai atau bersumber pada dasar filsafat negara yaitu pancasila. Pengertian inilah yang menunjukkan kedudukan dan fungsi pancasila sebagai dasar negara republik indonesia. Oleh karena itu secara formal yuridis pancasila di tetapkan sebagai dasar filsafat negara republik indonesia. 


\section{Penutup}

\section{Kesimpulan}

Nilai-nilai yang terdapat dalam pandangan hidup masyarakat, pandangan hidup bangsa dan pandangan hidup negara yang disebut dengan pancasila tidak bersifat statis. Artinya dalam kehidupan bermasyrakat, berbangsa, dan bernegara, ketiga bentuk pandangan hidup itu terus-menerus berinteraksi secara timbal-balik dan Selalu ada benang merah yang tidak boleh putus atau diputuskan diantara ketiganya.

Ajaran filsafat bernegara bangsa indonesia yang dibingkai dalam sebuah ideologi negara yang disebut pancasila merupakan landasan utama semua sistem penyelenggaraan negara indonesia.

Dalam sistem tertib hukum indonesia, penjelasan UUD 1945 menyatkan bahwa pokok pikiran itu meliputi suasana kebatinan dari undang-undang dasar negara indonesia serta mewujudkan cita-cita hukum, yang menguasai hukum dasar tertulis (UUD) dan hukum dasar tidak tertulis (konfrensi), selanjutnya pokok pikiran itu dijelmakan dalam pasal-pasal UUD 1945. Maka dapatlah di simpulkan bahwa suasana kebathinan undang-undang dasar 1945, tidak lain di jiwai atau bersumber pada dasar filsafat negara yaitu pancasila. Oleh karena itu secara formal yuridis pancasila di tetapkan sebagai dasar filsafat negara republik indonesia. Maka hubungan antara pembukaan UUD 1945 dengan pancasila bersifat timbal balik sebagi berikut yaitu Hubungan formal dan Hubungan material

Dengan bersendi pada jati diri Pancasila bukan bearti bangsa Indoesia menghendaki situasi status quo, yang tidak menghendaki perubahan. Karena perubahan tidak terletak pada esensi kwalitas jati diri, tetapi pada cara dan teknik dalam mengantisipasi tantangan yang dihadapi. Atau dapat pula dikatakan bahwa perubahan bukan pada tatanan dasar tetapi pada tatanan instrumental dan praksis. 


\section{Daftar Pustaka}

Darmini Roza dan Laurensius Arliman S Peran Pemerintah Daerah Di Dalam Melindungi Hak Anak Di Indonesia, Masalah-Masalah Hukum, Volume 47, Nomor 1, 2018.

Laurensius Arliman S, Komnas HAM dan Perlindungan Anak Pelaku Tindak Pidana, Deepublish, Yogyakarta, 2015.

Laurensius Arliman S, Penguatan Perlindungan Anak Dari Tindakan Human Trafficking Di Daerah Perbatasan Indonesia, Jurnal Selat, Volume 4, Nomor 1, 2016.

Laurensius Arliman S, Problematika Dan Solusi Pemenuhan Perlindungan Hak Anak Sebagai Tersangka Tindak Pidana Di Satlantas Polresta Pariaman, Justicia Islamica, Volume 13, Nomor 2, 2016.

Laurensius Arliman S, Pelaksanaan Perlindungan Anak Yang Tereksploitasi Secara Ekonomi Oleh Pemerintah Kota Padang, Veritas et Justitia, Volume 2, Nomor 1, 2016.

Laurensius Arliman S, Kedudukan Ketetapan MPR Dalam Hierarki Peraturan PerundangUndangan Di Indonesia, Lex Jurnalica, Volume 13, Nomor 3, 2016.

Laurensius Arliman S, Komnas Perempuan Sebagai State Auxialiary Bodies Dalam Penegakan Ham Perempuan Indonesia, Justicia Islamica, Volume 14, Nomor 2, 2017.

Laurensius Arliman S, Peranan Pers Untuk Mewujudkan Perlindungan Anak Berkelanjutan Di Indonesia, Jurnal Ilmu Hukum Tambun Bungai, Volume 2, Nomor 2, 2017.

Laurensius Arliman S, Mewujudkan Penegakan Hukum Yang Baik Untuk Mewujudkan Indonesia Sebagai Negara Hukum, Jurnal Hukum Doctrinal, Volume 2, Nomor 2, 2017.

Laurensius Arliman S, Participation Non-Governmental Organization In Protecting Child Rights In The Area Of Social Conflict, The 1st Ushuluddin and Islamic Thought International Conference (Usicon), Volume 1, 2017.

Laurensius Arliman S, Partisipasi Masyarakat Dalam Pembentukan Perundang-Undangan Untuk Mewujudkan Negara Kesejahteraan Indonesia, Jurnal Politik Pemerintahan Dharma Praja, Volume 10, Nomor 1, 2017, https://doi.org/10.33701/jppdp.v10i1.379.

Laurensius Arliman S, Peran Komisi Perlindungan Anak Indonesia Untuk Mewujudkan Perlindungan Anak, Jurnal Respublica Volume 17, Nomor 2, 2018.

Laurensius Arliman S, Menjerat Pelaku Penyuruh Pengrusakan Barang Milik Orang Lain Dengan Mempertimbangkan Asas Fungsi Sosial, Jurnal Gagasan Hukum, Volume 1, Nomor 1, 2019. 
Laurensius Arliman S, Ilmu Perundang-Undangan Yang Baik Untuk Negara Indonesia, Deepublish, Yogyakarta, 2019.

Laurensius Arliman S, Isdal Veri, Gustiwarni, Elfitrayenti, Ade Sakurawati, Yasri, Pengaruh Karakteristik Individu, Perlindungan Hak Perempuan Terhadap Kualitas Pelayanan Komnas Perempuan Dengan Kompetensi Sumber Daya Manusia Sebagai Variabel Mediasi, Jurnal Menara Ekonomi: Penelitian dan Kajian Ilmiah Bidang Ekonomi, Volume 6, Nomor 2, 2020.

Laurensius Arliman S, Pendidikan Kewarganegaraan, Deepublish, Yogyakarta, 2020.

Laurensius Arliman S, Makna Keuangan Negara Dalam Pasal Pasal 23 E Undang-Undang Dasar 1945, Jurnal Lex Librum, Volume 6, Nomor 2 Juni 2020, http://dx.doi.org/10.46839/1ljih.v6i2.151.

Laurensius Arliman S, Kedudukan Lembaga Negara Independen Di Indonesia Untuk Mencapai Tujuan Negara Hukum, Kertha Semaya Journal Ilmu Hukum, Volume 8, Nomor 7, 2020.

Laurensius Arliman S, Pelaksanaan Assesment Oleh Polres Kepulauan Mentawai Sebagai Bentuk Pelaksanaan Rehabilitasi Bagi Pecandu Dan Korban Penyalahgunaan Narkotika, Jurnal Muhakkamah, Volume 5, Nomor 1, 2020.

Laurensius Arliman S, Aswandi Aswandi, Firgi Nurdiansyah, Laxmy Defilah, Nova Sari Yudistia, Ni Putu Eka, Viona Putri, Zakia Zakia, Ernita Arief, Prinsip, Mekanisme Dan Bentuk Pelayanan Informasi Kepada Publik Oleh Direktorat Jenderal Pajak, Volume 17, No Nomor, 2020.

Larensius Arliman S, Koordinasi PT. Pegadaian (Persero) Dengan Direktorat Reserse Narkoba Polda Sumbar Dalam Penimbangan Barang Bukti Penyalahgunaan Narkotika, UIR Law Review, Volume 4, Nomor 2, 2020, https://doi.org/10.25299/uirlrev.2020.vol4(1).3779.

Laurensius Arliman S, Tantangan Pendidikan Kewarganegaraan Pada Revolusi 4.0, Ensiklopedia Sosial Review, Volume 2, Nomor 3, 2020.

Muhammad Afif dan Laurensius Arliman S, Protection Of Children's Rights Of The Islamic And Constitutional Law Perspective Of The Republic Of Indonesia, Proceeding: Internasional Conference On Humanity, Law And Sharia (Ichlash), Volume 1, Nomor 2, 2020 .

Otong Rosadi danLaurensius Arliman S, Urgensi Pengaturan Badan Pembinaan Idelogi Pancasila Berdasarkan Undang-Undang Sebagai State Auxiliary Bodies yang Merawat Pancasila dalam Perspektif Hak Asasi Manusia, Prosiding Konferensi Nasional Hak Asasi Manusia, Kebudayaan dan Tujuan Pembangunan Berkelanjutan Indonesia pada Masa Pandemi Covid-19: Tantangan untuk Keilmuan Hukum dan Sosial Volume 1, Universitas Pancasila, Jakarta, 2020. 
